(c) American Dairy Science Association, 2005.

\title{
Genetic and Phenotypic Relationships Among Milk Yield and Somatic Cell Count Before and After Clinical Mastitis
}

\author{
M. Koivula, E. A. Mäntysaari, E. Negussie, and T. Serenius \\ MTT Agrifood Research Finland, Animal Production Research, FIN-31600 Jokioinen, Finland
}

\begin{abstract}
This paper studies whether cows with originally lower somatic cell count (SCC) are more susceptible to clinical mastitis $(\mathrm{CM})$ than cows with higher somatic cell count, and evaluates the correlations between CM, SCC, and milk yield. Data were extracted from the Finnish national milk-recording database and from the health recording system. First and second lactation records of 87,861 Ayrshire cows calving between January 1998 and December 2000 were included. Traits studied were incidence of CM, test-day SCC, and test-day milk yield before and following CM. Genetic parameters were estimated using multitrait REML with a sire model. Results did not indicate that cows with genetically low SCC would be more susceptible to CM. The genetic correlation between $\mathrm{CM}$ in the first and second lactation was reasonably high (0.73), suggesting that susceptibility to mastitis remains similar across lactations. The genetic correlation between $\mathrm{CM}$ and milk yield traits was positive (from 0.38 to 0.56 ), confirming the genetic antagonism between production and udder health traits. The genetic correlation between SCC and milk was positive in the first lactation, but negative, or near zero in the second lactation. This indicates that breeding for lower SCC might not affect milk production in later lactations. The results of this study support the use of SCC as an indicator of mastitis and a tool for selection for mastitis resistance.
\end{abstract}

(Key words: somatic cell count, mastitis, genetic correlation, milk yield)

Abbreviation key: $\mathbf{C M}=$ clinical mastitis .

\section{INTRODUCTION}

Mastitis remains one of the major diseases in dairy herds, causing profound economic losses to the entire milk production chain. Therefore, strategies to reduce mastitis are important in decreasing costs and improv-

Received October 22, 2003

Accepted August 27, 2004.

Corresponding author: Minna Koivula; e-mail: minna.koivula@ mtt.fi. ing the quality of production. However, mastitis also causes suffering for the animals, and for ethical and animal welfare reasons therefore, it is important to consider mastitis in dairy cattle breeding. Finland, Sweden, Denmark, and Norway are the only countries with well-established national health recording systems and the only countries to include clinical mastitis (CM) directly in the national selection objectives for dairy cattle (Heringstad et al., 2000).

Direct selection for mastitis resistance has been considered inefficient because the heritability of mastitis is low (Lund et al., 1994; Pösö and Mäntysaari, 1996). In addition, most countries do not widely record CM incidences. Therefore, indirect measures of udder health, such as SCC, have been an appealing alternative (e.g., Emanuelson et al., 1988; Philipsson et al., 1995; Pösö and Mäntysaari, 1996). The heritability of SCC is higher than that of CM, and it reflects both subclinical and clinical mastitis (e.g., Lund et al., 1994; Pösö and Mäntysaari, 1996). Somatic cell count is routinely recorded in most milk recording systems, and information on SCC is easily available on a large scale. The efficiency of SCC as a selection criterion for mastitis resistance depends on the genetic correlation between the 2 traits; a moderate to high correlation has been shown in a wide range of studies (Mrode and Swanson, 1996; Pösö and Mäntysaari, 1996; Kadarmideen and Pryce, 2001). Thus, in most cases when there are no records for CM, improving udder health has widely been based on indirect selection for lower SCC.

Elevation of SCC is a clear indication of infection in the udder. However, somatic cells are also present in milk of healthy cows, and the increase in SCC is a normal cellular defense against udder infections. There has been much debate about whether breeding for lower SCC would be unwise in selection for mastitis resistance. Some studies have indicated that cows with very low SCC levels may be more susceptible to mastitis than cows with higher SCC (Kehrli and Shuster, 1994; Suriyasathaporn et al., 2000; Beaudeau et al., 2002). Studies based on experimental infection of cows have reported that animals resisting udder infection have higher SCC before the pathogenic infection than animals that become infected (Shuster et al., 1996; Schuk- 
ken et al., 1998). Moreover, in many countries, increased incidences of mastitis caused by environmental pathogens (especially Escherichia coli) have been reported to be associated with low SCC (e.g., Erskine et al., 1988). On the other hand, several studies report that low lactation mean SCC does not increase the susceptibility of cows to clinical mastitis (Rupp and Boichard, 2000; Rupp et al., 2000; Boettcher et al., 2002). Thus, we need to recognize that while selection against cows with high SCC is supposed to reduce mastitis incidence, the dilemma is whether SCC should be decreased to the lowest possible level, or should not be lowered below some critical threshold.

The aim of this study was to determine whether SCC is an efficient indicator of clinical mastitis, whether cows with initially low SCC are more resistant to mastitis infection, and how milk production is related to udder health traits. This was carried out by studying the relationships among SCC, CM, and test-day milk yield before and after mastitis incidents.

\section{MATERIALS AND METHODS}

The data used for this study were extracted from the Finnish national milk-recording database and the Finnish health recording scheme. The data comprised first and second lactation test-day records of Ayrshire cows whose calving dates were between January 1998 and December 2000. To include records from the second lactation, cows were required to have records from the first lactation. Only herds with at least 6 heifers per year were included in the analyses. Moreover, to ensure active participation in the health recording system, only herds with at least 2 disease recordings per year were accepted. Finally, the data included 87,861 cows in 3945 herds. The mean calving age was $26.2 \mathrm{mo}$ at the first calving and $39.2 \mathrm{mo}$ at the second calving.

Cows in the data were daughters of 1221 sires, with an average of 73 daughters per sire. After completing the sire and maternal grandsire information, the size of the pedigree was 1655 sires. For animals with a mastitis record, the date of the first mastitis record was used for $\mathrm{CM}=1$. For the healthy cows, the date of $\mathrm{CM}=0$ in the first and second lactation was randomly sampled from the distributions of DIM of the CM $=1$ group. Before analyses, the data on SCC records were transformed to a $\log _{\mathrm{e}}$ scale. The test-day data were rearranged to get 5 traits per lactation. The traits were clinical mastitis $(\mathrm{CM})$, test-day milk yield before the $\mathrm{CM}\left(\right.$ milk $\left._{\mathrm{b}}\right)$, test-day milk yield following the $\mathrm{CM}\left(\right.$ milk $\left._{\mathrm{f}}\right)$, SCC before the CM $\left(\mathrm{SCC}_{\mathrm{b}}\right)$, and SCC following the $\mathrm{CM}$ $\left(\mathrm{SCC}_{\mathrm{f}}\right)$. Milk and SCC observations were chosen to be the nearest test-day records before and after the date of $\mathrm{CM}$ record. However, $\mathrm{SCC}_{\mathrm{b}}$ was ignored if clinical mastitis was recorded less than a week after the SCC measurement. This was done because SCC levels would not represent the baseline level so close to the CM record, and could already be high due to infection.

Heritabilities and (co)variance components for the 10 traits from the 2 lactations were estimated from seven 5 -variate REML runs with a sire model using DMU (Madsen and Jensen, 2000). The following linear model was used for milk and SCC traits:

$$
\mathrm{y}_{\mathrm{ijklmn}}=\operatorname{age}_{\mathrm{i}}+\mathrm{sea}_{\mathrm{j}}+\mathrm{h}_{\mathrm{k}}+\sum_{\mathrm{t}=1}^{3} \mathrm{~b}_{\mathrm{t} 1} \phi_{\mathrm{dim}}^{\mathrm{t}}+\operatorname{add}_{\mathrm{m}}+\mathrm{e}_{\mathrm{ijklmn}},
$$

where $y_{i j k l m n}$ is an observation for a trait for cow $n$, age ${ }_{i}$ is the fixed effect of calving age, sea $a_{j}$ is the fixed effect of the calving season-calving year, $\mathrm{h}_{\mathrm{k}}$ is the fixed effect of a herd, $\sum_{\mathrm{t}=1}^{3} \mathrm{~b}_{\mathrm{t} 1} \phi_{\mathrm{dim}}^{\mathrm{t}}$ is a regression of DIM, with $\phi_{\text {dim }}^{1}$ and $\phi_{\text {dim }}^{2}$ the linear and quadratic terms of Legendre polynomials at DIM, and $\phi_{\text {dim }}^{3}$ an exponential term ex$\mathrm{p}\left(\mathrm{c}^{*} \operatorname{dim}\right)$ (Wilmink, 1987), the term $\mathrm{c}$ being -0.05 for milk, and -0.09 for SCC (Negussie et al., 2002), $\operatorname{add}_{\mathrm{m}}$ is the random sire additive genetic effect, and $\mathrm{e}_{\mathrm{ijklmn}}$ is the residual effect. The same linear model was used for the CM, but without the regression effects:

$$
\mathrm{y}_{\mathrm{ijkmn}}=\operatorname{age}_{\mathrm{i}}+\mathrm{sea}_{\mathrm{j}}+\mathrm{h}_{\mathrm{k}}+\operatorname{add}_{\mathrm{m}}+\mathrm{e}_{\mathrm{ijkmn}}
$$

For the analysis of CM, a linear sire model was used, although theoretically a threshold model would be more appealing for an analysis of binary data (Gianola, 1982). However, it is known that if the frequency of disease is more than $10 \%$, and the difference in frequency between animal groups (e.g., age classes) is less than 3 -fold, the estimates for genetic correlations from a linear model are very similar to the estimates from the threshold model (e.g., Mäntysaari et al., 1991). However, heritability calculated on the binary scale varies with incidence because the amount of variance due to measurement error depends on the incidence. Dempster and Lerner (1950) suggested a simple relationship by which heritabilities can be converted from the binary to the liability scale as follows:

$$
\mathrm{h}_{\mathrm{c}}^{2}=\mathrm{h}_{01}^{2}\left[\mathrm{p}(1-\mathrm{p}) / \mathrm{z}^{2}\right]
$$

where $\mathrm{h}_{\mathrm{c}}^{2}$ is the heritability in continuous scale and $\mathrm{h}_{01}^{2}$ the corresponding heritability calculated on binary scale, $p$ is the incidence of affected individuals in the population, and $\mathrm{z}$ is the ordinate of the standard normal density function on the threshold corresponding to $\mathrm{p}$.

Estimates from 7 separate REML runs were averaged to form additive genetic $\left(\mathbf{G}_{0}\right)$ and residual (co)variance 
Table 1. Number of observations, means, and SD of SCC and milk production before and after clinical mastitis (CM).

\begin{tabular}{|c|c|c|c|c|c|c|}
\hline \multirow[b]{2}{*}{ Trait } & \multicolumn{3}{|c|}{$\mathrm{CM}=0$} & \multicolumn{3}{|c|}{$\mathrm{CM}=1$} \\
\hline & $\mathrm{n}$ & Mean & $\mathrm{SD}$ & $\mathrm{n}$ & Mean & SD \\
\hline \multicolumn{7}{|l|}{ First lactation } \\
\hline $\mathrm{CM}(\%)$ & 77,518 & 88.2 & & 10,343 & 11.8 & \\
\hline Milk before CM (kg) & 49,561 & 20.9 & 6.09 & 5731 & 22.1 & 6.35 \\
\hline Milk following CM (kg) & 60,929 & 22.9 & 5.47 & 8621 & 23.0 & 5.40 \\
\hline $\log _{\mathrm{e}} \mathrm{SCC}$ before CM & 24,256 & 4.11 & 1.24 & 2461 & 4.90 & 1.54 \\
\hline $\log _{\mathrm{e}} \mathrm{SCC}$ following CM & 57,474 & 3.95 & 1.16 & 8219 & 4.28 & 1.38 \\
\hline \multicolumn{7}{|l|}{ Second lactation } \\
\hline $\mathrm{CM}(\%)$ & 35,080 & 85.1 & & 6153 & 14.9 & \\
\hline Milk before CM (kg) & 25,710 & 24.5 & 8.72 & 4054 & 26.9 & 8.97 \\
\hline Milk following CM (kg) & 26,856 & 28.0 & 8.03 & 5155 & 28.5 & 7.74 \\
\hline $\log _{\mathrm{e}} \mathrm{SCC}$ before CM & 12,496 & 4.41 & 1.29 & 1672 & 4.99 & 1.50 \\
\hline $\log _{\mathrm{e}} \mathrm{SCC}$ following CM & 25,486 & 4.18 & 1.27 & 4887 & 4.55 & 1.46 \\
\hline
\end{tabular}

matrices $\left(\mathbf{R}_{0}\right)$ of order $10 \times 10$. To assure that the outcome becomes positive definite the combining was done using the method of expanded part matrices (Mäntysaari, 1999). Standard errors of the estimated genetic correlations and heritabilities were obtained by averaging the error estimates from 7 REML runs.

In addition to correlations, the genetic relationships between the $\mathrm{CM}$ and SCC before the $\mathrm{CM}$ were assessed by examining the breeding values of sires obtained from the variance component model. This was done using the 386 bulls that had more than 50 daughters.

\section{RESULTS AND DISCUSSION}

\section{Data}

The overall means and standard deviations for the different traits are presented in Table 1 . The frequency of mastitis was highest at the beginning and again increased slightly at the end of lactation (Table 2, Figure 1 ), and the average DIM for CM = 1 was $109 \mathrm{~d}$ for the first lactation and $114 \mathrm{~d}$ for the second lactation. For $\mathrm{CM}=0$, the average DIM was 139 and $143 \mathrm{~d}$ for the first and second lactation, respectively. The mean and SD of test-day milk and SCC were higher in the second lactation compared with the first lactation (Table 1).

Table 2. Distribution of clinical mastitis by weeks from calving.

\begin{tabular}{llrlrr}
\hline & \multicolumn{2}{c}{ First lactation } & & \multicolumn{2}{c}{ Second lactation } \\
\cline { 2 - 3 } Weeks & $\mathrm{n}$ & & & $\mathrm{n}$ & $\%$ \\
\hline 1 to 8 & 5458 & 52.77 & & 2806 & 45.60 \\
9 to 16 & 980 & 9.48 & & 928 & 15.08 \\
17 to 24 & 842 & 8.14 & & 666 & 10.82 \\
25 to 32 & 713 & 6.89 & & 468 & 7.61 \\
33 to 40 & 567 & 5.48 & & 356 & 5.79 \\
41 to 48 & 816 & 7.89 & & 450 & 7.31 \\
$>49$ & 967 & 9.35 & & 479 & 7.79 \\
\hline
\end{tabular}

Because most CM cases arise in early lactation, before the first testing takes place, there were relatively few records on SCC and milk yield before the CM. Moreover, the smaller proportion of $\mathrm{SCC}_{\mathrm{b}}$ records in $\mathrm{CM}=1$ than in the $\mathrm{CM}=0$ group was due to censoring the SCC measurements that were taken less than one week before the mastitis record. The overall frequency of mastitis was $11.8 \%$ in the first, and $14.9 \%$ in the second lactation. These are higher than the 5.4 and $7.9 \%$ reported in Pösö and Mäntysaari (1996), but lower than 28.5\% reported for year 2001 in the Finnish health recordings (Rautala, 2002). However, the last number includes all incidences (including repeated incidences of the same cow), all lactations, and all breeds, whereas our data consist only of the first cases of mastitis per lactation in Ayrshires.

\section{Heritability}

Heritability estimates for traits included in this study are presented in Table 3 . The heritability of CM estimated on the observed binary scale was 0.02 for both lactations. Similarly, the estimate on the underlying continuous scale (Dempster and Lerner, 1950) was 0.05 for both lactations. In the literature, heritability estimates for clinical mastitis in most other studies have been low, ranging from 0.001 to 0.06 , with most values falling in the interval from 0.02 to 0.03 (Pösö and Mäntysaari, 1996; Heringstad et al., 2000). However, designed field studies (e.g., Nash et al., 2000) as well as estimates from analyses with threshold models (Heringstad et al., 2003) showed higher estimates, suggesting that heritability of clinical mastitis could be near $10 \%$.

Estimates of heritability for SCC were 0.07 and 0.08 for the first and second lactations, respectively (Table 3 ). Moreover, the estimates of heritability for SCC be- 


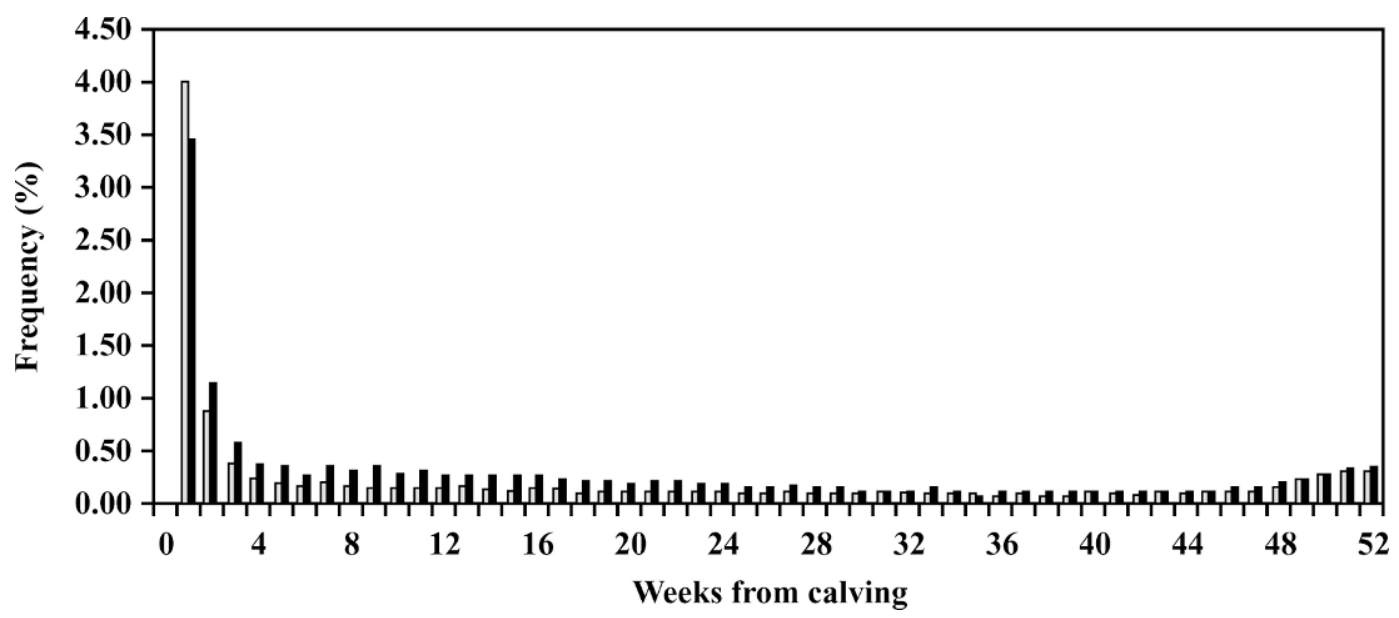

Figure 1. Frequency of clinical mastitis in the first (gray bars) and second (black bars) lactation expressed as a percentage of animals infected per week from calving.

fore and after the CM did not differ noticeably. The estimates of heritability obtained for SCC in this study lie well in the range (0.05 to 0.19$)$ reported in several other studies (Mrode and Swanson, 1996; Mrode et al., 1998; Koivula et al., 2004).

The heritability of test-day milk production was higher for first lactation compared with the second lactation, being on 0.11 and 0.09 , respectively (Table 3). The estimates are generally similar to those reported by Veerkamp and Goddard (1998) and Mäntysaari (1999). Moreover, heritability of test-day milk before and after $\mathrm{CM}$ were similar. In general, heritability estimates for the milk yield traits were quite low compared with the estimates from some other studies using test-day records (e.g., Haile-Mariam et al., 2001). Possible explanations for this could be that a sire model was used in this study and the fact that AI bulls are a highly selected population.

\section{Genetic and Phenotypic Correlations}

Genetic and phenotypic correlations between CM, SCC, and test-day milk yield are presented in Table 3. The genetic correlation between CM in the first and second lactation was 0.73 , indicating that susceptibility to mastitis persists across lactations. Genetic correlation between SCC traits before and after CM was 0.98 and 0.92 for the first and second lactations, respectively. However, correlations across lactations were somewhat lower $(0.69$ to 0.91$)$. A similar trend of higher withinlactation correlation (0.99) and lower across-lactation correlation ( 0.83 to 0.84 ) was observed for test-day milk yield.

Clinical mastitis and SCC traits had strong positive genetic correlation in the first and second lactation $(0.59$ to 0.68 ), although the correlations were slightly lower in the second lactation. Literature estimates of genetic correlations between SCC and clinical mastitis vary from moderate to high, with an average estimate of 0.70 (Mrode and Swanson, 1996; Heringstad et al., 2000). This is in close agreement with the estimates obtained in this study. Both genetic and phenotypic correlations indicated that high SCC increases the susceptibility to mastitis. This was revealed by the high correlations between CM and SCC before CM. High correlations between SCC and mastitis confirm that both are expressions of udder health, and thus SCC could be used as an indirect selection criterion for mastitis resistance.

From the linear relationship found between $\mathrm{CM}$ and SCC it has been concluded that it is possible to improve resistance to mastitis by selecting for low SCC (Philipsson et al., 1995; Nash et al., 2000). However, some papers have proposed a curvilinear relationship between the risk of mastitis and SCC, where the risk of mastitis increases if the SCC drops below some critical level (e.g., Kehrli and Shuster, 1994; Peeler et al., 2003). Therefore, relationships between EBV for CM and SCC before the CM were examined. In Figure $2 \mathrm{~A}$ and $\mathrm{B}$, the EBV for CM are plotted against EBV for SCC before the CM. As expected, the highest EBV for SCC were associated with the highest EBV for CM. The distributions of the EBV seemed slightly skewed and thus only few bulls had low EBV for either of the traits. The curvilinearity was tested by fitting a quadratic regression of CM on SCC before the CM. The test revealed significant quadratic coefficient $(P<0.01)$ in the first lactation but not in the second lactation $(P>0.1)$. From Figure 2, however, it can be concluded that the curvilinearity is caused by the nature of SCC as a mastitis 
A.

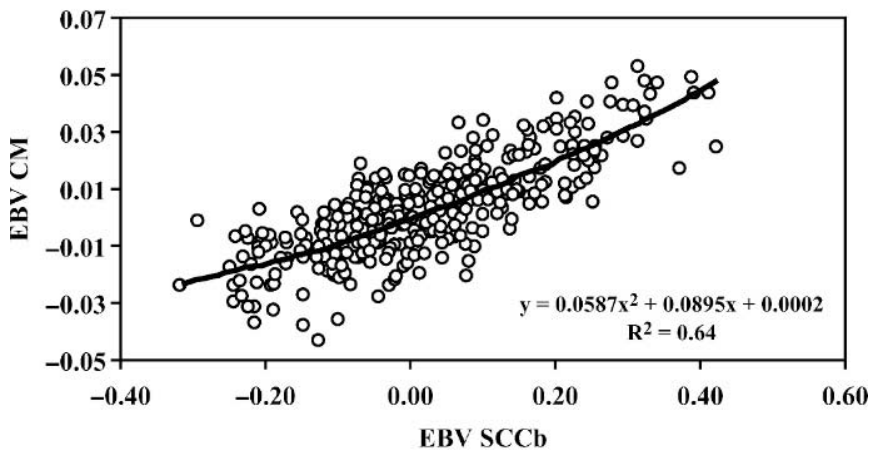

B.

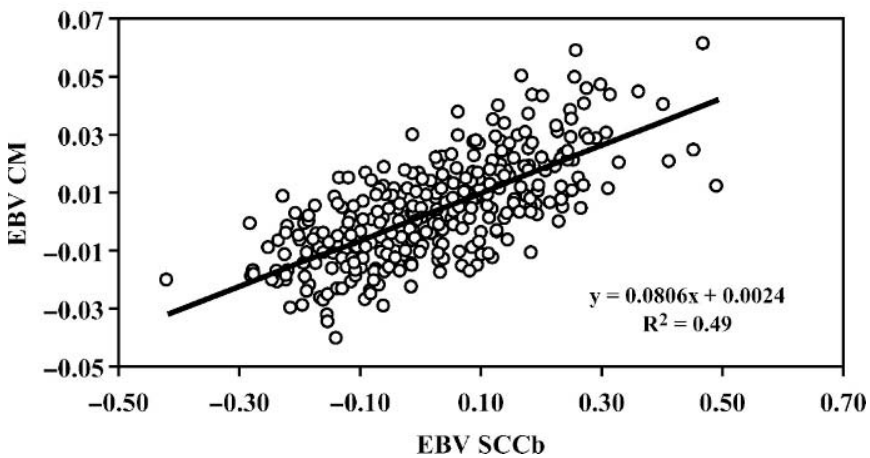

Figure 2. Regression of estimated breeding values of bulls (with at least 50 daughters) for clinical mastitis (CM) on estimated breeding values for SCC before the CM (SCCb). A) First lactation, B) Second lactation.

indicator. There seems to be a weak relationship to CM for bulls with below average EBV for SCC, because at the lower end, the slope seems to be much less. However, for bulls with higher than average EBV for SCC before CM the relationship is clear.

Several studies have not noted any increase in susceptibility to clinical mastitis for cows with low SCC (Rupp and Boichard, 2000; Rupp et al., 2000; Boettcher et al., 2002). Also, when the duration and severity of mastitis has been taken into account, it is observed that daughters of sires transmitting higher SCC have more severe and longer lasting clinical episodes (Nash et al., 2002). Furthermore, Rupp et al. (2000) suggested that cows with the lowest mean SCC in the first lactation have the lowest risk for clinical mastitis in the second lactation; thus, breeding goals should favor cows with low SCC. However, there is still the possibility that risk of mastitis increases if the SCC drops below some critical threshold.

Even though SCC recordings were ignored when mastitis was reported less than a week after SCC test-day, there is the possibility that some animals were already infected on the test-day. Thus, the conclusion that high SCC increases the susceptibility to clinical mastitis 
might not be fulfilled. Therefore, we calculated the (co)variance components after removing SCC records greater than 250,000 cell $/ \mathrm{mL}$ before the mastitis record. The removal of very high SCC before the CM did not affect the conclusions of the study: animals with genetically higher SCC were more vulnerable to mastitis (genetic correlation between $\mathrm{CM}$ and SCC before the CM was 0.54 for both lactations). On the other hand, most $\mathrm{CM}$ cases appeared at early lactation, before the first test-day, and there was a relatively small number of SCC and milk records before the CM. Therefore, results from this study are probably weighted toward the relationship of prior SCC and CM in mid and late lactation. Thus the possibility that the cows with an early lactation CM may have low levels of SCC due to a poor immune defense cannot be rejected. However, there are studies suggesting that low SCC in early lactation does not necessarily lead to low immune defense. For example, in a study by De Haas et al. (2002), it was found that cows with low SCC during early lactation are not more susceptible to CM.

The present study confirmed the genetic antagonism between production and udder health. The genetic correlation between $\mathrm{CM}$ and test-day milk yield was found to be positive ( 0.38 to 0.58 ), with the higher correlation observed in the second lactation. Moreover, the genetic correlation between $\mathrm{CM}$ and milk before the $\mathrm{CM}$ was at the same level as correlation between $\mathrm{CM}$ and milk following the CM. This unfavorable genetic association has been demonstrated by different studies (Pösö and Mäntysaari, 1996; Heringstad et al., 1999; Rupp and Boichard, 1999; Hansen et al., 2000), and indicates that animals with genetically high productivity are more susceptible to mastitis. Unfavorable associations between high milk yield and mastitis were less apparent in phenotypic correlations where CM and test-day milk yield before CM had only weak positive phenotypic correlation $(0.03$ in the first and 0.06 in the second lactation). In both lactations, $\mathrm{CM}$ and milk following $\mathrm{CM}$ had a negative correlation $(-0.05)$, thus mastitis incidence slightly decreased milk production (Table 3). However, these correlations are probably underestimates because CM was bivariate.

The genetic correlation between SCC and test-day milk yield was positive in the first lactation and near zero in the second lactation (Table 3). Most studies have reported unfavorable genetic correlations in the first lactation, i.e., high milk yield associated with high SCC (reviewed by Mrode and Swanson, 1996). In the later lactations, however, lower or negative genetic correlations have been observed. Phenotypic correlations between SCC and milk traits, on the other hand, were negative in both lactations (Table 3). This follows from the effect of high SCC to decrease the production. The negative phenotypic correlation between milk traits and SCC, and the increase in negative association with parity is also in agreement with the earlier studies (Mrode and Swanson, 1996; Haile-Mariam et al., 2001).

Two opposing mechanisms have been suggested to contribute to the genetic correlations between milk yield traits and SCC (e.g., Schutz et al., 1990; HaileMariam et al., 2001). On the one hand, cows with high milk yield may be more susceptible to mastitis resulting in a positive correlation in the first lactation. On the other hand, mastitis causes high SCC and damage to the udder, which reduces the second lactation milk yield and causes a negative correlation (Haile-Mariam et al., 2001). The changing balance between these mechanisms during the life of the animal could explain the changes in the correlation. In addition, culling practices that remove cows with low production and high SCC lead to a situation where most of the cows that will have second and later lactations are cows with low SCC and high milk yield. The fact that genetic association between milk and SCC changes from positive to zero or negative indicates that in later lactations, breeding for lower SCC might not result in lower milk production. However, the goal is to reduce mastitis, and the unfavorable genetic association between production and health must be taken into account.

\section{CONCLUSIONS}

High positive genetic correlation between SCC and $\mathrm{CM}$ indicates that both traits are expressions of udder health, and supports the use of SCC as an indirect measure of udder health. The results from this study do not indicate that cows with low initial SCC are more susceptible to mastitis or that cows with high initial SCC are more likely to be healthy. Genetic correlation between SCC and milk traits was positive in the first lactation, and near zero in the second lactation. Thus, it seems that in later lactations, selection for lower SCC would not necessarily result in lower productivity, and at the same time SCC can be used as an indirect tool to select for mastitis resistance. This is the only option when $\mathrm{CM}$ incidences are not routinely recorded. When $\mathrm{CM}$ records are available, selection could be directly against CM and information on SCC could be used as a correlated character in estimation of breeding values. If information on both traits is available, a combined evaluation will lead to more accurate prediction of breeding values for mastitis resistance.

\section{ACKNOWLEDGMENTS}

We thank Antti Kause for valuable comments on the manuscript. 


\section{REFERENCES}

Beaudeau, F., C. Fourichon, H. Seegers, and N. Bareille. 2002. Risk of clinical mastitis in dairy herds with a high proportion of low individual milk somatic-cell counts. Prev. Vet. Med. 53:43-54.

Boettcher, P., A. Samoré, and G. Pagnacco. 2002. Relationship between normal levels of somatic cells and the duration of mastitis infections. Proc. 7th World Congr. Genet. Appl. Livest. Prod., Montpellier, France, CD-ROM communication No. 09-23.

De Haas, Y., H. W. Barkema, and R. F. Veerkamp. 2002. Effect of pathogen-specific clinical mastitis on lactation curves for somatic cell count. J. Dairy Sci. 85:1314-1323.

Dempster, E. R., and I. M. Lerner. 1950. Heritability of threshold characters. Genetics 35:212-236.

Emanuelson, U., B. Danell, and J. Philipsson. 1988. Genetic parameters for clinical mastitis, somatic cell counts, and milk production estimated by multiple-trait restricted maximum likelihood. J. Dairy Sci. 71:467-476.

Erskine, R. J., R. J. Eberhart, L. J. Hutchinson, S. B. Spencer, and M. A. Cambell. 1988. Incidence and types of clinical mastitis in dairy herds with high and low somatic cell counts. JAVMA 192:761-765.

Gianola, D. 1982. Theory and analysis of threshold characters. J. Anim. Sci. 54:1079-1096.

Haile-Mariam, M., P. J. Bowman, and M. E. Goddard. 2001. Genetic and environmental correlations between test-day somatic cell count and milk yield traits. Livest. Prod. Sci. 73:1-13.

Hansen, M., M. S. Lund, M. K. Sørensen, and L. G. Christensen. 2000. Genetic parameters of dairy character, protein yield, clinical mastitis, and other diseases in the Danish Holstein cattle. J. Dairy Sci. 85:445-452.

Heringstad, B., G. Klemetsdal, and J. Ruane. 1999. Clinical mastitis in Norwegian cattle: Frequency, variance components, and genetic correlation with protein yield. J. Dairy Sci. 82:1325-1330.

Heringstad, B., G. Klemetsdal, and J. Ruane. 2000. Selection for mastitis resistance in dairy cattle: A review with focus on the situation in the Nordic countries. Livest. Prod. Sci. 64:95-106.

Heringstad, B., R. Rekaya, D. Gianola, G. Klemetsdal, and K. A. Weigel. 2003. Genetic change for clinical mastitis in Norwegian cattle: A threshold model analysis. J. Dairy Sci. 86:369-375.

Kadarmideen, H. N., and J. E. Pryce. 2001. Genetic and economic relationships between somatic cell count and clinical mastitis and their use in selection for mastitis resistance in dairy cattle. Anim. Sci. 73:229-240.

Kehrli, M. E., and D. E. Shuster. 1994. Factors affecting milk somatic cell and their role in health of the bovine mammary gland. $\mathrm{J}$. Dairy Sci. 77:619-627.

Koivula, M., E. Negussie, and E. A. Mäntysaari. 2004. Genetic parameters for test-day somatic cell score (SCC) at different stages of lactation in Finnish Ayrshire cattle. Livest. Prod. Sci. 90:145-157.

Lund, T., F. Miglior, J. C. M. Dekkers, and E. B. Burnside. 1994. Genetic relationship between clinical mastitis, somatic cell count, and udder conformation in Danish Holsteins. Livest. Prod. Sci. 39:243-251.

Madsen, P., and J. Jensen. 2000. Users' guide to DMU: A package for the analysis of multivariate mixed models. Danish Institute of Agricultural Sciences (DIAS), Dept. of Animal Breeding and Genetics Research Centre Foulum, Tjele, Denmark.

Mäntysaari, E. A. 1999. Derivation of multiple trait reduced rank random regression (RR) model for the first lactation test day records of milk, protein and fat. Page 2 in Proc. 50th Annu. Mtg. Eur. Assoc. Anim. Prod., Zurich, Switzerland, Wageningen Pers, Wageningen, The Netherlands.

Mäntysaari, E. A., R. L. Quaas, and Y. T. Gröhn. 1991. Simulation study on covariance component estimation for two binary traits in an underlying continuous scale. J. Dairy Sci. 74:580-591.
Mrode, R. A., and G. J. T. Swanson. 1996. Genetic and statistical properties of somatic cell count and its suitability as an indirect means of reducing the incidence of mastitis in dairy cattle. Anim. Breed. Abstr. 64:847-857.

Mrode, R. A., G. J. T. Swanson, and M. S. Winters. 1998. Genetic parameters and evaluations for somatic cell counts and its relationship with production and type traits in some dairy breeds in the United Kingdom. Anim. Sci. 66:569-576.

Nash, D. L., G. W. Rogers, J. B. Cooper, G. L. Hargrove, and J. F. Keown. 2002. Relationships among severity and duration of clinical mastitis and sire transmitting abilities for somatic cell score, udder type traits, productive life, and protein yield. J. Dairy Sci. 85:1273-1284.

Nash, D. L., G. W. Rogers, J. B. Cooper, G. L. Hargrove, J. F. Keown, and L. B. Hansen. 2000. Heritability of clinical mastitis incidence and relationships with sire transmitting abilities for somatic cell score, udder type traits, productive life, and protein yield. J. Dairy Sci. 83:2350-2360.

Negussie, E., M. Koivula, and E. Mäntysaari. 2002. Application of test-day models in genetic evaluation of Finnish dairy cattle for somatic cell count. Page 25 in Proc. Annu. Mtg. Eur. Assoc. Anim. Prod., Cairo, Egypt. Wageningen Pers, Wageningen, The Netherlands.

Peeler, E. J., M. J. Green, J. L. Fitzpatrick, and L. E. Green. 2003. The association between quarter somatic-cell counts and clinical mastitis in three British dairy herds. Prev. Vet. Med. 59:169-180.

Philipsson, J. G., G. Ral, and B. Berglund. 1995. Somatic cell count as a selection criterion for mastitis resistance in dairy cattle. Livest. Prod. Sci. 41:195-200.

Pösö, J., and E. Mäntysaari. 1996. Relationships between clinical mastitis, somatic cell score, and production for the first three lactations of Finnish Ayrshire. J. Dairy Sci. 79:1284-1291.

Rautala, H. 2002. Terveystarkkailun tulokset 2001. Nauta 32:48-49.

Rupp, R., F. Beaudeau, and D. Boichard. 2000. Relationship between milk somatic cell counts in the first lactation and clinical mastitis. Prev. Vet. Med. 46:99-111.

Rupp, R., and D. Boichard. 1999. Genetic parameters for clinical mastitis, somatic cell score, production udder type traits, and milking ease in first-lactation Holsteins. J. Dairy Sci. 82:21982204.

Rupp, R., and D. Boichard. 2000. Relationship of early first lactation somatic cell count with risk of subsequent clinical mastitis. Livest. Prod. Sci. 62:169-180.

Schukken, Y. H., K. E. Leslie, D. A. Barnum, B. A. Mallard, J. H. Lumsden, P. C. Dick, G. H. Vessie, and M. E. Kehrli. 1998. Experimental Staphylococcus aureus intramammary challenge in late lactation dairy cows: Quarter and cow effects determining the probability of infection. J. Dairy Sci. 82:2393-2401.

Schutz, M. M., L. B. Hansen, G. R. Steuernagel, J. K. Reneau, and A. L. Kuck. 1990. Genetic parameters for somatic cells, protein, and fat in milk of Holsteins. J. Dairy Sci. 73:494-502.

Shuster, D. E., E. K. Lee, and M. E. Kehrli, Jr. 1996. Bacterial growth, inflammatory cytokine production, and neutrophil recruitment during coliform mastitis in cows within ten days after calving, compared with cows at midlactation. Am. J. Vet. Res. 57:15691575.

Suriyasathaporn, W., Y. H. Schukken, M. Nielen, and A. Brand. 2000. Low somatic cell count: A risk factor for subsequent clinical mastitis in a dairy herd. J. Dairy Sci. 83:1248-1255.

Veerkamp, R. F., and M. E. Goddard. 1998. Covariance functions across herd production levels for test day records on milk, fat and protein yields. J. Dairy Sci. 81:1690-1701.

Wilmink, J. B. M. 1987. Adjustment of test-day milk, fat and protein yields for age, season, and stage of lactation. Livest. Prod. Sci. $17: 211$. 